\title{
BEYOND THE IVORY TOWER - HIGHER EDUCATION INSTITUTIONS AS CULTURAL RESOURCE CASE STUDY OF THE QUEENSLAND CONSERVATORIUM OF MUSIC
}

\begin{abstract}
This paper focuses on the interface between higher education and the arts, in particular the role of the music school or conservatorium as a cultural resource. The genesis of the Queensland Conservatorium of Music leading to its establishment in 1957 in Brisbane Australia, and its subsequent development to the early 1990s, is used as a case study. Perceptions of cultural cringe, both in respect to the northern hemisphere and also the southern Australian states, have been lively discussion points in Queensland's artistic development for many years. The foundation of the Queensland Conservatorium was therefore viewed as a cultural emblem of mature statehood, and threats to its survival have been debated in this light. The unique socio-political dynamics of the state, whose capital city Brisbane is far removed from regional centres, also play into any study of Queensland's artistic development. The conservatorium's cultural value in contributing to society as a talent pool, incubator of original work, and as an arts centre, is examined. Evidence that the relationship between academia and the broader arts community can be both symbiotic and ambivalent is also presented, largely through analysis of the mass print media, where much of the early history of Queensland Conservatorium is documented.
\end{abstract}

Professor Peter Roennfeldt, Queensland Conservatorium Griffith University, Brisbane Australia.

Peter Roennfeldt's recent research has focussed on the social history of Australian music, an area where he also worked during his early academic studies. He has published articles in The Oxford Companion to Australian Music, The Australian Dictionary of Biography, and has curated recordings of heritage repertoire for the 'Music Queensland' project of the State Library of Queensland. He is currently writing a history of the Queensland Conservatorium Griffith University, where he has taught for more than twenty years and also served until recently as its Director. As a keyboard performer and conductor he has specialised in early music on period instruments, and has created performing editions of baroque works from original sources. His work on French composers has recently resulted in a chapter within the Festschrift for Wiley Hitchcock, New Perspectives on Charpentier published by Ashgate. Roennfeldt holds bachelors and masters degrees from the Universities of Queensland and Adelaide respectively, and a Doctor of Musical Arts from the University of Cincinnati. 
Ivory towers, art(ist) incubators and the 'edifice complex' - what do these have in common? Do university music schools have a role to play in the creation of new art(forms) as well as preservation of the cultural heritage of the community which supports them? A comforting statement in this regard was contained in a recent review of Australian higher education, which asserted that the sector 'will continue to be a cornerstone of our legal, economic, social and cultural institutions'. ${ }^{1}$ However, while social inclusion issues were prominent in the Bradley Review, the value of cultural and performing arts disciplines within higher education was barely mentioned. As a further indicator of where the arts stand within education overall, the sector had to lobby strongly during the Australian national curriculum debate, to ensure their ongoing presence alongside 'core' subject areas. ${ }^{2}$ Politically speaking, the working environments of educational institutions and cultural policy continue without little intersection, despite their obvious synergies. ${ }^{3}$

The political need to self-justify and fend off threats to survival is a constantly recurring theme in the story of music within Australia's post-school (tertiary) institutions. ${ }^{4}$ One recent crisis was documented in the 2001 film Facing the Music, which examined the near demise of the Music Department within the University of Sydney. ${ }^{5}$ Surprisingly, this led to some positive outcomes including generous benefactions, and significant critical acclaim. ${ }^{6}$ The media coverage surrounding the recent amalgamation of the Victorian College of the Arts and the University of Melbourne demonstrates that artistic disciplines continue to face financial and political challenges in the early $21^{\text {st }}$ century. ${ }^{7}$

This article examines the notion of 'cultural value' of music education institutions. It draws on the fields of social history, higher education policy, and performing arts studies, areas which usually do not intersect. However, as public debates about the role of performing arts schools demonstrate, these fields collectively underpin their rationale for existence. It is hoped that this article will contribute to a potentially potent area of study, namely the interface between academia and culture.

This discussion is informed by the rather specialised genre of 'institutional histories', which to date includes only a few volumes focussing on the Australian conservatorium (music school). ${ }^{8}$ The case study is the Queensland Conservatorium of Music (QCM), founded in 1957, and which by the 1980s was recognised as a significant cultural entity. On becoming a college of Griffith University in 1991, it was claimed as a virtual state icon. ${ }^{9}$ The QCM's establishment arose from a popularly subscribed agenda that saw cultural maturity embodied in state-supported artistic institutions, which can be traced through the mass media as well as the more rarefied forum of parliamentary debate. This commentary informs responses to the question: "to what extent is a conservatorium a cultural as well as educational institution, and how does it balance these sometimes competing expectations?” 
Australian life is constantly affected by its regional diversity and demographic inequalities. Due to being centrally located within their highly populated states, the capital cities of Sydney (New South Wales NSW) and Melbourne (Victoria) have dominated Australia's artistic consciousness. In these cities, cultural institutions and audiences achieved critical mass much earlier than other states. Meanwhile Adelaide (South Australia), as the 'third metropolis', ${ }^{10}$ had a heritage distinct from the eastern cities. Based on free settlement rather than convict origins, it also had a higher proportion of non-British (mainly German) inhabitants, many of whom played key cultural roles. Unsurprisingly, Australia’s first three conservatoria were established in these cities: the Faculty of Music at the University of Melbourne (1891), the Elder Conservatorium at the University of Adelaide (1898), and the State Conservatorium of New South Wales in Sydney (1915).

The cultural hegemony of Adelaide-Melbourne-Sydney as a 'southern state triumvirate' outshone the outlying states of Queensland, Western Australia and Tasmania. Overlaid on this was a Eurocentric bias that great artists only came from the northern hemisphere, or at least trained there. Therefore a strongly held Queensland view was the lack of its own conservatorium reinforced its inferiority to the rest of Australia and the rest of the world - a double 'cultural cringe'. Inspired by the recent example of his hometown Sydney, Robert Dalley-Scarlett wrote in 1920 that a conservatorium in the state capital of Brisbane 'would serve to centralise the musical life and interests of the city'. ${ }^{11}$ George Sampson echoed this in 1927: 'with a conservatorium Brisbane, at least, would have a chance of holding her own musically against the other States, and be a rallying point for all the musicians in Queensland' ${ }^{12}$

Queensland's regional decentralisation is unique within Australia, and furthermore its capital is somewhat inconveniently located in the state's southeast corner. Brisbane's population has been consistently less than $50 \%$ of the state total, a much lower rate than all other capitals. The 1940s was a decisive decade for Queensland's development, with the virtual occupation of Brisbane by American armed forces, and later post-war economic expansion. ${ }^{13}$ By the 1947 census when it attained greater status as the new 'third metropolis’, surpassing Adelaide’s size, ${ }^{14}$ Brisbane’s artistic life had also been quietly developing.

It is virtually unknown today that the state government's education department sponsored a touring professional string quartet from 1944-1952. It was originally led by Ernest Llewellyn, who later founded the Canberra School of Music, and who in 1947 wrote a seminal document on the need for a conservatorium, using research into interstate and overseas practices. ${ }^{15}$ That year also saw the Queensland Symphony Orchestra (QSO) inaugurated as Australia's second large professional ensemble 
playing classical music. Significantly, many of its players were recruited from interstate. The creation of a state orchestra and string quartet begged the question as to where future instrumentalists might study, and why not locally?

The reality for talented Queensland musicians was that their only option for higher education was interstate or overseas. A 'cultural diaspora’ persisted in the 1950s with many leaving permanently, such as pianists Margaret Barton, Winifred Burston, Marjorie Hesse, Ronald and Ruth Farren-Price, singers Margaret Baker, Emily Hammond and Helen McKinnon, and composer Ron Grainer. This perpetual ‘talent drain’ precipitated strong arguments favouring a local music school, supported by evidence that nearly forty Queenslanders were then studying in Sydney. ${ }^{16}$

Thus pro-conservatorium arguments focussed on human resources as a pre-requisite for cultural growth. In the meantime, increasing government support created the fledgling State Opera Scheme, comprising a troupe of trainee singers. ${ }^{17}$ If Queensland could boast its own orchestra, a string quartet, and now an opera ensemble, why not an elite music school? Politicians were rather uncommital until more compelling factors surfaced. This occurred in 1951, when the NSW Conservatorium announced a new regional branch in Newcastle. With the hyperbolic headline 'A Piece of News That Should Make Brisbane Blush: Big City Takes a Bad Beating’, ${ }^{18}$ the agenda now extended to state and civic pride.

The press campaign had gathered pace from the 1940s, with arguments ranging from the need for heightened artistic standards ${ }^{19}$ to the general imperative a 'pre-requisite for musical progress'. ${ }^{20}$ A lighter series of articles ‘If Women ran Queensland' appointed violinist Gloria Foley as hypothetical Minister of Arts and Music, stating her primary aim of establishing a conservatorium. ${ }^{21}$ Despite growing public activism, and a mention in Premier Hanlon’s 1950 election campaign speech, parliamentarians found reasons to delay. ${ }^{22}$ Hanlon's mantle as a 'great supporter of a conservatorium ${ }^{23}$ was thrust upon Vince Gair who became Premier in 1952. Having previously commented on the 'need for culture here', ${ }^{24}$ the Government soon approved 'in principle' the founding of a conservatorium. ${ }^{25}$ While the educational function of a proposed conservatorium was not disregarded, by aligning it with broader socio-cultural issues, the argument for higher music education gained weight.

The 'centre of music in the state'

The Queensland Conservatorium of Music opened in February 1957, with foundation director William Lovelock and three inaugural lecturers in violinist Basil Jones, singer Peter Martin and pianist Rex Hobcroft. Press commentary on the event is illuminating. One editorial described it as 'a new and important advance in the State's cultural and educational development'. ${ }^{26}$ Another major article asserted 
'the Conservatorium will be the State's musical headquarters. It will train local talent locally. It will be a community musical centre as well as a school'. ${ }^{27}$ Within hours of the opening, an afternoon edition described 'an important day in the cultural history of the State', ${ }^{28}$ reporting that the Premier officiated in the presence of government, church, business, music and educational leaders.

This triumphant initiation spoke strongly to QCM's cultural as well as educational significance. Several parliamentary speeches also attest to political ownership of this cultural agenda. One particularly colourful personality was Tom Aikens from Townsville in northern Queensland. ${ }^{29}$ Cognisant of regional issues, he continually posed questions regarding the advisability of QCM's location within the capital, ${ }^{30}$ and the need for distance-based equity scholarships. ${ }^{31}$

The new conservatorium made immediate public impacts. Lovelock conducted his own composition at a choral festival, ${ }^{32}$ while a professional development seminar drew many teachers from around Queensland and interstate. ${ }^{33}$ QCM became the regular venue for the Musica da Camera Society, presenting chamber music concerts until its cessation in $1972 .{ }^{34}$ These three strands of community interface - newly created original work, professional expertise, cultural infrastructure - would recur throughout subsequent decades. Summarising the first year's operations, Roger Covell cited various student-based and extramural activities as evidence of 'a real centre of musical activity for the whole community'. ${ }^{35}$

After preliminary fanfares subsided, realities emerged that most students were part-timers, ${ }^{36}$ and the gender balance amongst full-time undergraduates was decidedly female. ${ }^{37}$ Even though students had been recruited from interstate ${ }^{38}$ and overseas, ${ }^{39}$ some early graduates moved away due to lack of work opportunities, a complaint voiced by second director Basil Jones. ${ }^{40}$ Authorities including visiting conductor Nikolai Malko added to the debate, stating in 1958 'production of trained instrumentalists by conservatoriums and music schools was not keeping pace with Australia’s musical progress', particularly the 'less popular orchestral instruments'. ${ }^{41}$

Therefore, much significance was given to the first sign of QCM achieving one of its 'state' objectives, with the appointment of clarinet student Rodney Jacobsen to the QSO in 1960. This was declared 'a step forward in the music of Queensland', as the 'first product' of the QCM to achieve professional credibility. ${ }^{42}$ This premature dawn was questioned later when Parliament, as if there was 'something wrong' with the conservatorium initiative, since QCM was not 'fulfilling the purpose for which it was established', as Jacobsen's case was still unique in the mid 1960s. ${ }^{43}$ The training of future orchestral musicians had been a major plank of the lobbying campaign, so for some stakeholders the explicit link between education and cultural sector employment needed stronger reinforcement as soon as possible. 
With hindsight it might have been foreseen that most enrolments would be in piano or voice, areas which do not necessarily lead to definable early career positions.

\section{Cultural and professional resource}

The surfeit of vocal students in the young QCM drew attention from national performing companies. When the Elizabethan Theatre Trust Opera Company requested extra choristers for its Brisbane seasons, QCM gladly assisted. ${ }^{44}$ Thus for the 1958 season, which included the Australian premiere of Benjamin Britten's Peter Grimes, QCM students participated in Carmen and Lohengrin. ${ }^{45}$ The relationship with QCM as a talent pool continued until the late 1960 s, ${ }^{46}$ when the company reconstituted itself as the Australian Opera. Thus QCM quickly became a vital resource for the professional scene, albeit occasionally.

Several QCM teachers were in demand for major engagements immediately upon arrival. The piano lecturers were in the top rank, featuring as Australian Broadcasting Commission (ABC) concerto soloists. Larry Sitsky and Max Olding were noted for $20^{\text {th }}$ century composers, ${ }^{47}$ while Nancy Weir associated more with mainstream Germanic repertoire. ${ }^{48}$ Violin lecturer Ladislav Jasek, whose Brisbane debut was as an international ABC artist, maintained a profile as a high calibre resident soloist. ${ }^{49}$ Singing lecturers were also active in oratorio and symphonic concerts, notably James Christiansen and Janet Delpratt. Had these and other eminent musicians not been appointed to QCM, it is doubtful whether as many local performers would have appeared with major national performing organisations.

Higher education institutions, and particularly universities, are expected to not only preserve their academic disciplines, but also extend them through fostering of new work through scholarly research, particularly in the sciences and humanities. One musical corollary to the production of new knowledge is original composition. Lovelock composed quite prolifically, though his series of fourteen concertos appeared after he left QCM. ${ }^{50}$ Theory lecturer Lloyd Vick was also less prominent until retirement, but by then had several works international publications. ${ }^{51}$ Sitsky quickly became Brisbane's enfant terrible, a phenomenon which every self-respecting cultural community seems to foster. He introduced the concepts of musique concrète, acoustic instruments alongside pre-recorded tapes, and used astringently dissonant textures in some compositions. One of his events even inspired a political cartoon - a sure sign of notoriety. ${ }^{52}$ Sitsky achieved prominence during 1965 with theatrical work that was prophesied as 'the answer to the future of Australian opera'. ${ }^{53}$ QCM was in small but significant ways expanding the music domain through such creativity. 
The South Brisbane QCM building was regularly used as a performance venue, despite its obvious limitations. The grand Italianate 1890s building was refurbished after various configurations as meeting rooms, American army headquarters, and also post-war accommodation. Its 120-seat auditorium was a useful addition to Brisbane's concert venues, which mainly comprised the 1,000-seat Albert Hall and the even larger City Hall. ${ }^{54}$ Like most music schools internationally, in-house and externally produced performances became a regular feature. Within its first decade QCM hosted Musica da Camera recitals, ABC events, Dante Alighieri Society concerts, and professional bodies including the Fellowship of Australian Writers and the Guild of Australian Composers.

While these activities are not in themselves particularly remarkable, the mixed profile of QCM being a professional talent pool, an incubator of creative work, and also a small arts centre, meant it was a welcome contributor to the cultural ecosystem. This mixed profile would later expand and consolidate, sometimes at risk of compromising its tertiary education focus.

Fast forward to the 1980s - on par with major cultural institutions

When QCM relocated in 1975 to a purpose-built facility at Gardens Point, its operations grew exponentially. Its location adjacent to the Queensland Institute of Technology was intended to facilitate dialogue with other higher education providers, but amalgamation with them was not envisaged. Of greater significance was its inner city presence, providing easier access to public performances than a less central location could provide. When these decisions were made during the late 1960s, future expansion of Brisbane's cultural infrastructure may not have been imagined, but the need to facilitate public engagement seemed axiomatic for a conservatorium. The recently appointed state Director of Cultural Activities Arthur Creedy commented it was 'ironic’ that while the QCM was moving into the city, the other state cultural education institution, Queensland College of Art, was moving to the suburbs. ${ }^{55}$ It remained there until 2001, until it moved to the South Bank campus where it is now a sister college to the Conservatorium.

With arrival of third director Roy Wales in 1981, QCM's ambitions for broader impact expanded. The 1980s was also a time of cultural ferment for Brisbane, with both the 1982 Commonwealth Games and Expo88 enlivening community spirit and extending cultural aspirations. Between these events, the Queensland Performing Arts Complex (later Centre - QPAC) opened in 1985, also changing community expectations. $^{56}$

As the Commonwealth Games' cultural counterpart, Festival '82 profiled various local organisations. QCM contributed with a 'Benjamin Britten Festival' - comprising two operas and his War Requiem. The 
latter performance demonstrated an expanded ensemble program, and whose success led to the formation of the Brisbane Chorale. This 150-voice symphonic chorus soon competed with the state's iconic century-old choir for QSO symphonic concerts. Including both students and a community contingent, the Brisbane Chorale presented local premieres such as Berlioz' Grande Messe des Morts, ${ }^{57}$ the Australian premiere of Bernstein’s Mass, ${ }^{58}$ and much other neglected repertoire.

The QCM Opera School also produced numerous landmarks. During the 1980s and 1990s it presented Australian premieres of Menotti's The Saint of Bleeker Street, ${ }^{59}$ and Weill's Street Scene, ${ }^{60}$ and Britten's Billy Budd. ${ }^{61}$ QCM also provided performers for QPAC's opening celebration events, and also the state opera company's inaugural production in the new venue. ${ }^{62}$ Undeniably, QCM was now a major cultural player alongside professional arts companies. This enhanced external profile was welcomed as 'decentralization' into ‘the outside music scene'. ${ }^{6}$

Other major QCM events included the 1981 Brisbane Twentieth Century Music Festival which featured 20 events and more than 30 living composers, many of whom were personally present. ${ }^{64}$ An Ethnic Music Festival in 1983 focussed on Asia-Pacific cultures, ${ }^{65}$ at a time when multiculturalism was a relatively new concept in Australia. The visits of eminent composer Michael Tippett in $1984^{66}$ and $1990^{67}$ also drew attention to QCM as an exponent of contemporary music. This profile was further enhanced through major involvement with the Musica Nova Festivals, presented by the ABC in 1987 and 1990. Major composers such as Witold Lutoslawski visited QCM to hear their works performed. ${ }^{68}$

At government level, two keynote events at Gardens Point signified the institution’s continuing preeminence. The new building was officially opened in 1975 by the then state Governor Sir Colin Hannah, and the $25^{\text {th }}$ anniversary in 1982 saw the state Premier Joh Bjelke-Petersen officially launching a major building extension. Such appearances may be primarily symbolic, but they speak of significant standing in the socio-political landscape.

Not all was however harmonious in terms of relationships between the Conservatorium and some in the local community. Music lovers had recently witnessed the sudden demise of the Queensland Opera Company, which functioned as a fully professional ensemble from 1970 to $1980{ }^{69}$ The Lyric Opera of Queensland, which arose as a phoenix from the thespian ashes in mid-1982, ${ }^{70}$ however soon found itself without a venue due to the sudden demolition of Brisbane's major proscenium theatre. ${ }^{71}$ The muchlamented destruction of heritage buildings concurrently with a cultural infrastructure construction program during the 1980s created such anomalies due to mismatched agendas and timelines. 
Meanwhile, QCM was presenting up to four annual opera seasons of varied repertoire to a high standard, ${ }^{72}$ attracting strong public audiences. The Conservatorium's formation of a new semiprofessional opera company, in 1984, was however the final straw for some stakeholders. This was seen as overstepping boundaries, with unfair advantage as a government-funded educational institution. ${ }^{73} \mathrm{~A}$ press war ensued. In its defence, the QCM director sought to explain how additional productions were self-funding, and that Colleges of Advanced Education such as the Conservatorium were expected to 'reflect the needs of the communities it serves' and contribute to local activities. ${ }^{74}$ It was also suggested that the QCM's facilities could have helped alleviate the opera company's temporary venue shortage. This brief skirmish revealed a volatile undercurrent, in that if a tertiary institution embarks on a highly public program, how could this be justified when other local operations suffered due to increasing 'unfair' competition. A similar concern was implicit within the increasingly competitive areas of choral music ${ }^{75}$ and pre-tertiary music education, ${ }^{76}$ fields where QCM significantly expanded during the mid-1980s.

\section{Collective ownership of a conservatorium as a cultural icon}

As stated earlier, crisis points act as a gauge for community ownership of higher education. The first flashpoint in QCM's history occurred even before the first graduates had completed their 3-year diploma, when Lovelock refused to be considered for re-appointment from mid-1959. Concerns raised included his claim of bureaucratic interference upon a director's discretionary or academic responsibilities. Lovelock also asserted 'those responsible for the functioning of the Conservatorium did not want to understand its real function as a centre of culture for Queensland'. ${ }^{77}$

The barrage of press coverage included nearly seventy pieces in a three week period, including six front page articles. One editorial echoed sentiments confirming the state’s moral ownership of QCM, including the need to retain local students rather than again lose them to elsewhere. The institution was again considered a 'real centre of musical culture in Queensland, rather than a mere music-teaching annexe of the Education Department'. ${ }^{78}$ Such views demonstrated a generally held view of QCM as a collectively owned cultural resource, and the impending threat to the state's identity if the Conservatorium's status was in question.

The next crisis occurred in 1981 when a Commonwealth Parliamentary Committee, affectionately termed 'The Razor Gang', recommended to the Commonwealth Tertiary Education Committee that smaller colleges such as QCM should merge with larger institutions. The suggested host was the Queensland Institute of Technology, whose campus was directly adjacent. The state education minister immediately voiced objections to the proposal, which was also 'strongly rejected' by the Cabinet, ${ }^{79}$ and supported by their federal counterparts. ${ }^{80}$ Arguments which were used by these supporters included the view that 
QCM's 'place in the Queensland cultural scheme had to be preserved at all costs'. ${ }^{81}$ An editorial again asserted the QCM's state cultural role:

The conservatorium is not involved merely in the research and theory of music. It makes musicians. It makes music

... Going south should not need to start again, a quarter of a century later. Queensland, in music training, should not be allowed to become an inferior place. ${ }^{82}$

Thus as its $25^{\text {th }}$ anniversary approached, QCM's independence seemed assured for the foreseeable future. Meanwhile, four teacher training colleges lost their individual identity, merging to form the Brisbane College of Advanced Education.

In the heady 1980s atmosphere, with major cultural events and new arts organisations coming to the fore, it might seem self-evident that QCM would remain a stand-alone specialist institution. But when the next round of federal reforms involving amalgamations was proposed in 1988, voicing of the same arguments, as expressed only seven years earlier, was to no avail. Press commentary identified QCM's 'important role in Brisbane’s community life'. ${ }^{83}$ As before, cost-cutting fears were articulated, while the argument 'big is not beautiful' was also made. ${ }^{84}$ To a greater extent than previously, macro-economic issues were invoked, an indication of the utilitarian phase that higher education was now entering. In State Parliament, it was further noted that because QCM 'has a very great role to play in the cultural affairs of Queensland, it should be allowed to stand alone', but approaches to the Federal Minister on that score were unsuccessful, so local negotiators had to 'make the best of the situation in which they have been placed' ${ }^{85}$ However, with massification of the university sector, increased provision of places could only be justified if a user-pays philosophy were also introduced. For institutions such as QCM, with its relatively higher per-student costs, this was a particularly dangerous direction, and an ongoing fear since joining the university sector in 1991.

Around the time of transition to its new status as a university college, the phrase 'jewel in the crown' was used colloquially to denote the wider cultural significance of QCM. Together with the other major state institution, the Queensland College of Art, QCM's arrival was hailed as a major strategic benefit to Griffith University, a relatively young and small institution. Griffith’s Vice-Chancellor Roy Webb asserted 'the Conservatorium will continue to be a focal point for the cultural enrichment of Queensland through its performance-oriented programs' ${ }^{86}$ It was almost as if the previous rhetoric regarding QCM's status as a cultural emblem of statehood had become university policy. After the numerous working parties had dealt with blending of course structures, governance and staffing arrangements, Webb then initiated a full review of Griffith's artistically focussed elements, with a view to preserving the identity of each faculty’s cultural activities, while also highlighting synergies and potential for future interdisciplinary collaborations. ${ }^{87}$ 
Just before amalgamation, the first regional campus in Mackay North Queensland was established. From 1989 until it was transferred to Central Queensland University in 1996, this vibrant small campus instantly became a focal point for much local music-making, in similar if not greater proportions to what had occurred in Brisbane. As a catalyst for local developments in orchestral music, jazz and opera, the campus attracted numerous experienced musicians to work in northern Queensland. A timely indication of its contribution to local culture was provided in 1995 where the review of the Gala Concert noted 'just how tuned-in this lively director is to the needs of her students and the community in which the campus operates'.88

The eventual relocation to the South Bank cultural precinct adjacent to QPAC in 1996 further embodied the QCM’s broader artistic status. Its major venue, a multi-purpose 600-seat proscenium theatre, immediately enhanced local cultural infrastructure. A frequent user was the state opera company, whose needs as a co-tenant had informed key planning decisions. A synergy that had developed was that two major organisations, one primarily educational and the other artistic, could be accommodated in a single facility. A compromise out of financial necessity thus also created mutual benefits. ${ }^{89}$ The convergence of philosophical viewpoints with practical concerns was publicly articulated:

This will be no ivory tower cosseted from public gaze. The tax-paying public will be as welcome as the students ... 'Sharing it with Opera Queensland will ensure the co-operation of the two institutions in the professional development of students'. ${ }^{90}$

The Conservatorium as a cultural resource - square peg in round hole?

The subsequent history of QCM is beyond the limits of this article. The question remains whether its founders' aspirations have been realised in being a 'centre of music in the state'. The early $17^{\text {th }}$ century Italian conservatorio were initially benevolent providers of musical education for society’s less fortunate children, but their performances soon became a 'must see' for the cultural tourist. ${ }^{91}$ The Paris Conservatoire founded in the 1790s similarly fostered some of France's major orchestral concerts in the early $19^{\text {th }}$ century. ${ }^{92}$ As the institutional model developed further in Germany, ${ }^{93}$ the UK, ${ }^{94}$ and the USA, ${ }^{95}$ artistic connections were forged, particularly through appointment of eminent musicians as teachers. The first two Australian conservatoria were founded within universities, a remarkable exception to the pervading model of music schools as elite single-discipline specialist institutions, though each was collectively 'owned' by their local community. Thus when QCM was established in 1957, the historically validated model of a stand-alone music school was pre-eminent, as was the community focussed cultural role.

The 'build it and they will come' notion is often used to support new cultural infrastructure, sometimes leading to an 'edifice complex'. 96 The minimum standard requirement of a major city to have each of 
the standard performance companies (orchestra, opera, ballet and theatre) has been cited by contemporary social theorists as an increasingly outmoded model that has previously served as a proxy for cultural maturity. ${ }^{97}$ The destiny of a conservatorium is very much linked to its own local cultural context. The journey described above is one of complementary developments within the music profession and the educational infrastructure which supports it. But is a conservatorium to be limited to merely showcasing its own talents within purely academic contexts, or can it rightfully aspire to mainstage status? Is it able to contribute to the dynamic landscape of the arts world, and thus be a player in the broader interaction between cultural communities and academia? Furthermore, how does this dual and sometimes competing responsibility impact upon its ability to produce not only satisfactory university graduates, but also the 'home grown' artists it was established to nurture?

In the case of QCM, which was founded to foster home-grown talent, a symbiotic relationship existed from the start. The public came in for performances, and students and staff went out for professional engagements. New original work was created and curated on-campus within an environment relatively safe from commercial constraints, and some was being heard well beyond its walls. Community-focussed ensembles and activities permitted two-way dialogue and engagement, even if the boundaries sometimes blurred between 'education' and 'arts', causing occasional tensions. In the particular case of opera, QCM has frequently complemented the standard repertoire of professional companies with local premieres of new or rarely heard works, something which longstanding commentators cite as a great institutional strength. $^{98}$

Mutually satisfying interactions can exist between academia and the external 'real' world. But the track record of Australia's conservatoria, and their dealings with the internal academic structures they have been compelled to adopt, is quite variable. With now twenty years' experience with the university sector, Australian music schools have been transformed in various ways, with many experiencing crisis points along the way, and some even closure or absorption into larger entities. Comforting assertions of iconic status are not always matched with adequate resourcing in a sector which requires constant accounting for staff and student 'outputs', including the vexed issue of defining research for creatively focussed academics. In the case of QCM, with its main campus being located within the state capital's cultural precinct, there is evidence of its premium place within the arts community. However, mere physical proximity does not always lead to close collaborations, and can even heighten perceptions of competition.

The creative tension between internally focussed educational functions and broader culture aspirations is something which will continue to be lived out within a conservatorium. It is further embodied in how academic facilities and their public programs interface with their community's arts scene. The first thirty years of QCM's history demonstrates that one role need not compromise the other, and in fact cross- 
sectoral dialogue is essential to maintain vibrancy and relevance. Despite this, perceptions will vary as to whether the notion of a 'conservatorium as cultural resource' will continue to exist within an increasingly complex environment. Since music in its many forms requires audiences for its survival, there is a strong chance it will never be totally constrained by its 'ivory towers', actual or imagined. An underlying tension is that education and culture have broader aims than the merely pragmatic and economic. But in order to survive, their institutions are inevitably drawn into the socio-political and economic arenas.

This case study of a single institution demonstrates that arguments in defence of higher education music institutions as cultural resource need to be continually reinforced. But the scenarios which have inspired the rhetoric, the aspirations and the achievements of such institutions have changed little over successive generations.

\footnotetext{
${ }^{1}$ D. Bradley, Review of Australian Higher Education - Final Report, Dec. 2008

< http://www.deewr.gov.au/HigherEducation/Review/Documents/PDF/Higher\%20Education\%20Review_one\%20document_0 2.pdf>, accessed 9 Aug. 2010.

${ }^{2}$ R. Letts, The National Curriculum and Strategic Advocacy for Music and the Arts, 10 Sep. 2009 <http://www.mca.org.au/pdf/mca_natcurricrationale.pdf $>$, accessed 9 Aug. 2010.

3 B. Haseman and L. Jaaniste, The arts and Australia's national innovation system 1994-2008: arguments, recommendations, challenges (Canberra: Council for Humanities, Arts and Social Sciences, 2008),

<http://www.chass.org.au/papers/PAP20081101BH.php>, accessed 17 Aug. 2010.

4 P. Roennfeldt, 'The genealogy and anatomy of the Australian tertiary music sector: How far have we come and where are we going?’, NACTMUS Conference, Brisbane, Australia, 1 Jul. 2007 < http://nactmus.org.au/PDF/Roennfeldt.pdf $>$, accessed 9 Aug. 2010.

${ }^{5}$ B. Connolly and R. Anderson, Facing the Music, (Lindfield: Film Australia with Arundel Films, 2001).

6 'Facing the Music', Wikipedia article, <http://en.wikipedia.org/wiki/Facing the_Music>, accessed 14 Aug. 2010.

${ }^{7}$ University of Melbourne, 'University provides strong support to VCAM, <htpp://blogs.unimelb.edu.au/musse/?p=1300>, accessed 14 Aug. 2010; and ‘The Australian: VCA = \$ for Uni Melb’ < http://savevca.org/archives/750>, accessed 14 Aug. 2010.

${ }^{8}$ K. Wiseman, From park to palace : a history of the Newcastle Conservatorium of Music, 1952-1986 (Newcastle: New South Wales Conservatorium, 1988); L. Edmiston and L. Stemler, Tasmanian Conservatorium: Beginning the journey - the first 25 years (Hobart: Tasmanian Conservatorium, 1990); P. Tregear, The Conservatorium of Music, University of Melbourne : an historical essay to mark its centenary 1895-1995 (Melbourne: Centre for Studies in Australian Music, 1997); J. Pascoe, Creating: The Victorian College of the Arts (Melbourne: Victorian College of the Arts, 2000); D. Collins, Sounds from the Stables : The Story of Sydney's Conservatorium (Sydney: Allen and Unwin, 2001). The current author is currently in the process of adding to this by writing the history of the first 50 years of Queensland Conservatorium Griffith University.

9 'Griffith and Conservatorium to amalgamate', The Courier-Mail, 11 Dec. 1990, 13.

${ }^{10}$ W. Hatherell, The Third Metropolis: Imagining Brisbane through Art and Literature 1940-1970 (Brisbane: University of Queensland Press, 2007).

11 'Conservatorium of Music: Mr Scarlett's Views', Daily Mail, 15 Apr. 1920, 4.

${ }^{12}$ G. Sampson, 'The Need of a Conservatorium or School of Music for Brisbane', Brisbane Music Week (1927), 26.

${ }^{13}$ R. Fitzgerald, A History of Queensland From 1915 to the 1980s (Brisbane: University of Queensland Press, 1984$), 107,187$.

${ }^{14}$ Hatherell, Third Metropolis, 18.

${ }^{15}$ E. Llewellyn, 'Proposal for Establishment of a Conservatorium of Music in Brisbane', (Brisbane: Typescript, 1947), Queensland State Archives document file PRV 7971.

${ }^{16}$ Queensland Conservatorium or School of Music Fund - Provisional Committee, Minutes of Meeting 18 Jul. 1950 , Queensland State Archives document file PRV 7971.

17 'Round the Studios', Australian Musical News, 1 Dec. 1949, 36.

${ }^{18}$ F. Rogers, 'A Piece of News That Should Make Brisbane Blush: Big City Takes a Bad Beating,' Brisbane Telegraph, 3 Nov. 1951, 4.

${ }^{19}$ R. Dalley-Scarlett, 'Chopin is played like Bing Crosby', The Courier-Mail, 1 Mar. 1946, 2.

${ }^{20}$ F. Rogers, 'Queensland needs a Conservatorium of Music', Brisbane Telegraph, 2 Feb. 1946, 2.

21 'If Women ran Queensland', The Courier-Mail, 5 Jan. 1953, 6.

22 E. Hanlon, Labor's Policy Speech, Delivered at Brisbane City Hall, 11 Apr. 1950 (Brisbane: Government Printer, 1950$), 14$.

${ }^{23}$ F. Rogers, ‘A Memorial Con? Music Loses a Friend’, Brisbane Telegraph, 19 Jan. 1952, 12.
} 
${ }^{24}$ E. Briggs, 'Govt. sees Need for Culture Here', The Courier-Mail, 3 Feb. 1951, 5.

25 'Move on Conservatorium by State Govt.', Brisbane Telegraph, 29 Jan. 1952, 2.

26 'State Aid for Music', The Courier-Mail, 13 Feb. 1957, 2.

27 'Worth a fanfare', The Courier-Mail, 16 Feb. 1957, 1.

28 'Conservatorium seen as State cultural event', Brisbane Telegraph, 16 Feb. 1957, 3.

${ }^{29}$ I. Moles, A Majority of One - Tom Aikens and Independent Politics in Townsville (Brisbane: University of Queensland Press, 1979), 46-47.

${ }^{30}$ T. Aikens, 'Conservatorium of Music in Country Towns,' speech in Queensland Parliament 26 Aug. 1954, Hansard 209 (1954-1955): 132.

${ }^{31}$ T. Aikens, 'Scholarships to Conservatorium of Music,' speech in Queensland Parliament 10 March 1964, Hansard 237 (1963-1964): 2300.

${ }^{32}$ F. Rogers, 'Fine work by choirs', Brisbane Telegraph, 16 May 1957, 18.

33 '130 Brushing up on Music', Courier-Mail, 17 Aug. 1957, 6.

${ }^{34}$ R. Dalley-Scarlett, 'Tram solos spoilt recital by quartet', The Courier-Mail, 9 May 1957, 9.

${ }^{35}$ R. Covell, 'Year-old 'Con' hits the right note', The Courier-Mail, 20 Nov. 1957, 2.

36 '290 at music set a problem', The Courier-Mail, 11 Feb. 1958, 5.

37 'Boys too shy, so girls are tops (or so he says)', Truth, 24 Nov. 1957, 14.

38 'Has won three scholarships', Brisbane Telegraph, 19 Mar. 1958, 5.

39 'The accent's on music: Catering for all at 'Con', The Courier-Mail, 9 Feb. 1960, 5.

40 'Music brains lost to State,' The Courier-Mail, 21 Nov. 1963, 8.

41 'Music needs 'key men', The Courier-Mail, 9 Apr. 1958, 12.

${ }^{42}$ F. Rogers, 'A new face, new era in State orchestra', Sunday Mail, 29 May 1960, 32.

43 'Something wrong with music policy', The Courier-Mail, 7 Oct. 1964, 13.

44 'Local singers for opera', The Courier-Mail, 5 May 1958, 5.

45 ' $£ 40,000$ operas on way', The Courier-Mail, 11 Jun. 1958, 12.

46 'Chorus for opera', The Courier-Mail, 4 Aug. 1966, 5.

${ }^{47}$ W. Lovelock, 'Conductor Cosma sincere, dedicated at Youth concert', The Courier-Mail, 9 Oct. 1963, 6.

${ }^{48}$ W. Lovelock, 'Second Beethoven concert first-rate', The Courier-Mail, 9 Nov. 1967, 6.

${ }^{49}$ W. Lovelock, 'First Beethoven was heartening', The Courier-Mail, 6 Nov. 1967, 6.

${ }^{50}$ William Lovelock (1899-1986): Represented Artist, Australian Music Centre,

$<$ http://www.australianmusiccentre.com.au/artist/lovelock-william>, accessed 14 Aug. 2010.

${ }^{51}$ Lloyd Vick: Represented Artist, Australian Music Centre, < $<$ http://www.australianmusiccentre.com.au/artist/vick-lloyd>, accessed 14 Aug. 2010.

52 'Concrete music recital', The Courier-Mail, 4 May 1962, 2.

${ }^{53}$ Pleiades, 'Answer to future of Australian opera', Hobart Mercury, 20 Aug. 1965, 2.

${ }^{54}$ Queensland Performing Arts Centre, Treading the boards: a survey of theatre buildings in Brisbane, 1847-1998 (Brisbane: Queensland Performing Arts Centre, 1999).

55 'Opposed to arts division', The Courier-Mail, 17 Aug. 1973, 11.

${ }^{56}$ D. Rowbotham, 'Opening a 'Cloud 9' event', The Courier-Mail, 22 Apr. 1985, 14.

57 J. Villaume, 'The Grand Vision of Berlioz', The Courier-Mail, 7 Jun. 1986, 40.

${ }^{58}$ J. Villaume, 'Bernstein's 'Mass' packs Concert Hall to capacity', The Courier-Mail, 12 Apr. 1986, 41.

${ }^{59}$ J. Villaume, 'Opera on the move', The Courier-Mail, 5 Aug. 1983, 2.

${ }^{60}$ J. Oliphant, 'Opera Bites Big Apple’, The Courier-Mail, 31 Aug. 1988, 44.

${ }^{61}$ B. Hebden, 'An Operatic Triumph', Sunday Mail, 30 May 1993, 145.

${ }^{62}$ J. Villaume, “'Aida' a spectacular triumph’, The Courier-Mail, 9 Aug 1985, 11.

${ }^{63}$ F. Rogers, 'Choral articulation was unusually clear', Sunday Mail, 20 May 1984, 54.

${ }^{64}$ J. Villaume, 'Music Festival ... in retrospect', The Courier-Mail, 11 Aug. 1981, 2.

${ }^{65} \mathrm{R}$. Wilson, 'Ethnic Music Week', The Courier-Mail, 12 May 1983, 2.

${ }^{66}$ J. Colwill, 'Bravo Michael Tippett', The Courier-Mail, 20 Mar. 1984, 2.

${ }^{67}$ B. Hebden, 'Talent shines through rain', The Courier-Mail, 29 Mar. 1990, 28.

${ }^{68}$ J. Colwill, 'Moving moments with Lutoslawski', The Courier-Mail, 11 Aug. 1987, 26.

${ }^{69}$ S. Da Costa-Roque, 'Light opera leader helps plan new opera company', Sunday Mail, 1 Feb. 1981, 2.

${ }^{70}$ T. Livingstone, 'Lyric Opera’s 6 aims’, The Courier-Mail, 10 Jun. 1982, 2.

${ }^{71}$ J. Phillips, 'Bonus for Brisbane’, The Courier-Mail, 7 Jul. 1983, 2.

${ }^{72}$ J. Villaume, 'Students triumph', The Courier-Mail, 6 Apr. 1982, 2.

${ }^{73}$ D. Bray, 'Govt's 'double aid' for opera queried', The Courier-Mail, 14 May 1984, 18.

${ }^{74} \mathrm{R}$. Wales, 'Opera role fills a local need', The Courier-Mail, 30 May 1984, 20.

75 'State choir wants voices', The Courier-Mail, 25 Sep. 1983, 24.

${ }^{76} \mathrm{~J}$. Colwill, 'Talent shows in lively student performances', The Courier-Mail, 4 Jun. 1984, 16.

77 'Lovelock hits rules thought', Brisbane Telegraph, 12 Jun. 1959, 4.

78 'Future of state music', The Courier-Mail, 9 Jun. 1959, 2.

79 'Cabinet rejects tertiary mergers', The Courier-Mail, 8 Jul. 1981, 10.

80 'Conservatorium merger 'killed', The Courier-Mail, 11Jul. 1981, 2.

81 'Music lovers rally to save conservatorium', The Courier-Mail, 6 Jul. 1981, 1. 
82 'A backward step on music', The Courier-Mail, 6 Jul. 1981, 4.

${ }^{83}$ B. Hebden, 'Small is the best: Leave Con alone!', The Courier-Mail, 24 May 1988, 37.

${ }^{84}$ T. Bray, 'Big is not beautiful', The Courier-Mail, 30 Nov. 1988, 8.

${ }^{85}$ Queensland Parliament Hansard, Second Reading of 'Queensland University of Technology and Brisbane College of

Advanced Education Bill’, 28 Mar. 1990, 884-5, <http://parlinfo.parliament.qld.gov.au/isysquery/a5aa8a10-49b7-4aa6-811ee5fe39445260/7/doc/900328ha.pdf\#xml=http://parlinfo.parliament.qld.gov.au/isysquery/a5aa8a10-49b7-4aa6-811ee5fe39445260/7/hilite/>, accessed 14 Aug. 2010.

86 'Griffith and Conservatorium to amalgamate', The Courier-Mail, 11 Dec. 1990, 13.

${ }^{87}$ M. Bonnin, The Arts at Griffith: A Vision Document (Brisbane: Griffith, University, 1991).

${ }^{88}$ P. Kelly, 'Mix of music's best', The Courier-Mail, 21 Sep. 1995, 30.

89 'Music moves to South Bank', The Courier-Mail, 18 Dec. 1992, 2.

${ }^{90}$ P. Kelly, 'Conservatorium moves home', The Courier-Mail, 19 Jun. 1996, 30.

${ }^{91}$ H. Landon and J. Norwich, Five Centuries of Music in Venice (London: Thames and Hudson, 1991), 119.

92 J. Mongrédien, trans. S. Frémaux, French Music from the Enlightenment to Romanticism: 1789-1830 (Portland: Amadeus, 1996), 215.

93 P. Cahn, Das Hoch'sche Konservatorium in Frankfurt am Main 1878-1978 (Frankfurt am Main: Kramer, 1979).

${ }^{94}$ H. Colles and J. Cruft, The Royal College of Music: A Centenary Record, 1883-1983 (London: Prince Consort Foundation, 1982).

95 A. Olmstead, Juilliard: A History (Urbana: University of Illinois Press, 1999).

${ }^{96}$ P. Kelly, 'The edifice complex', The Courier-Mail Weekend, 20 Jan. 1996, 13.

${ }^{97}$ R. Florida, The Rise of the Creative Class (New York: Basic Books, 2004), 182.

${ }^{98}$ P. Kelly, 'French double bill at the Con', Opera-Opera, 346 (Oct. 2006): 23.

\section{Bibliography}

Aikens, Tom, 'Conservatorium of Music in Country Towns,' speech in Queensland Parliament 26 Aug. 1954, Hansard 209 (1954-1955): 132.

Aikens, Tom, 'Scholarships to Conservatorium of Music,' speech in Queensland Parliament 10 March 1964, Hansard 237 (1963-1964): 2300.

Bonnin, Margriet, The Arts at Griffith: A Vision Document (Brisbane: Griffith, University, 1991).

Bradley, Denise, Review of Australian Higher Education - Final Report, Dec. 2008

$<\underline{\text { http://www.deewr.gov.au/HigherEducation/Review/Documents/PDF/Higher\%20Education\%20Review_one\%20document_0 }}$ 2.pdf>, accessed 9 Aug. 2010.

Bray, David, 'Govt’s ‘double aid’ for opera queried', The Courier-Mail, 14 May 1984, 18.

Bray, Theodore, 'Big is not beautiful', The Courier-Mail, 30 Nov. 1988, 8.

Brier, Percy, 'The Musical Association of Queensland - A Short History of 25 Year's Work April 1921 - April 1946’,

(Brisbane: Typescript, 1947), 2.

Briggs, Ernest, 'Govt. sees Need for Culture Here’, The Courier-Mail, 3 Feb. 1951, 5.

Cahn, Peter, Das Hoch'sche Konservatorium in Frankfurt am Main 1878-1978 (Frankfurt am Main: Kramer, 1979).

Colles, Henry, and Cruft, John, The Royal College of Music: A Centenary Record, 1883-1983 (London: Prince Consort Foundation, 1982).

Collins, Diane, Sounds from the Stables: The Story of Sydney's Conservatorium (Sydney: Allen and Unwin, 2001).

Colwill, John, ‘Bravo Michael Tippett’, The Courier-Mail, 20 Mar. 1984, 2.

Colwill, John, 'Talent shows in lively student performances', The Courier-Mail, 4 Jun. 1984, 16.

Colwill, John, 'Moving moments with Lutoslawski', The Courier-Mail, 11 Aug. 1987, 26.

Connolly, Bob, and Anderson, Robin, Facing the Music, (Lindfield: Film Australia with Arundel Films, 2001).

Covell, Roger, 'Year-old 'Con' hits the right note', The Courier-Mail, 20 Nov. 1957, 2.

Da Costa-Roque, Sylvia, 'Light opera leader helps plan new opera company’, Sunday Mail, 1 Feb. 1981, 2.

Dalley-Scarlett, Robert, 'Chopin is played like Bing Crosby’, The Courier-Mail, 1 Mar. 1946, 2.

Dalley-Scarlett, Robert, 'Tram solos spoilt recital by quartet', The Courier-Mail, 9 May 1957, 9.

Edmiston, Lyndal, and Stemler, Leon, Tasmanian Conservatorium: Beginning the journey - the first 25 years (Hobart:

Tasmanian Conservatorium, 1990).

Fitzgerald, Ross, A History of Queensland From 1915 to the 1980s (Brisbane: University of Queensland Press, 1984).

Florida, Richard, The Rise of the Creative Class (New York: Basic Books, 2004).

Hanlon, Edward Michael, Labor's Policy Speech, Delivered at Brisbane City Hall, 11 Apr. 1950 (Brisbane: Government

Printer, 1950), 14.

Haseman, Bradley, and Jaaniste, Luke, The arts and Australia's national innovation system 1994-2008: arguments,

recommendations, challenges (Canberra: Council for Humanities, Arts and Social Sciences, 2008),

<http://www.chass.org.au/papers/PAP20081101BH.php>, accessed 17 Aug. 2010.

Hatherell, William, The Third Metropolis: Imagining Brisbane through Art and Literature 1940-1970 (Brisbane: University of Queensland Press, 2007).

Hebden, Barbara, 'Small is the best: Leave Con alone!', The Courier-Mail, 24 May 1988, 37.

Hebden, Barbara, ‘Talent shines through rain’, The Courier-Mail, 29 Mar. 1990, 28. 
Hebden, Barbara, ‘An Operatic Triumph’, Sunday Mail, 30 May 1993, 145.

Kelly, Patricia, 'The edifice complex', The Courier-Mail Weekend, 20 Jan. 1996, 13.

Kelly, Patricia, 'Conservatorium moves home', The Courier-Mail, 19 Jun. 1996, 30.

Kelly, Patricia, 'French double bill at the Con', Opera-Opera, 346 (Oct. 2006): 23.

Landon, H. Robbins, and Norwich, Julius, Five Centuries of Music in Venice (London: Thames and Hudson, 1991$), 119$.

Letts, Richard, The National Curriculum and Strategic Advocacy for Music and the Arts, 10 Sep. 2009

$<$ http://www.mca.org.au/pdf/mca_natcurricrationale.pdf $>$, accessed 9 Aug. 2010.

Livingstone, Tess, 'Lyric Opera’s 6 aims’, The Courier-Mail, 10 Jun. 1982, 2.

Llewellyn, Ernest, 'Proposal for Establishment of a Conservatorium of Music in Brisbane’, (Brisbane: Typescript, 1947),

Queensland State Archives document file PRV 7971.

Lovelock, William, 'Conductor Cosma sincere, dedicated at Youth concert', The Courier-Mail, 9 Oct. $1963,6$.

Lovelock, William, 'First Beethoven was heartening', The Courier-Mail, 6 Nov. 1967, 6.

Lovelock, William, 'Second Beethoven concert first-rate', The Courier-Mail, 9 Nov. 1967, 6.

Moles, Ian, A Majority of One - Tom Aikens and Independent Politics in Townsville (Brisbane: University of Queensland Press, 1979).

Mongrédien, Jean, trans. S. Frémaux, French Music from the Enlightenment to Romanticism: 1789-1830 (Portland: Amadeus, 1996)

Oliphant, Jo, 'Opera Bites Big Apple’, The Courier-Mail, 31 Aug. 1988, 44.

Olmstead, Andrea, Juilliard: A History (Urbana: University of Illinois Press, 1999).

Pascoe, Joseph, Creating: The Victorian College of the Arts (Melbourne: Victorian College of the Arts, 2000).

Phillips, Juanita, 'Bonus for Brisbane’, The Courier-Mail, 7 Jul. 1983, 2.

Pleiades, ‘Answer to future of Australian opera', Hobart Mercury, 20 Aug. 1965, 2.

Queensland Conservatorium or School of Music Fund - Provisional Committee, Minutes of Meeting 18 Jul. 1950, Queensland

State Archives document file PRV 7971.

Queensland Parliament Hansard, Second Reading of 'Queensland University of Technology and Brisbane College of

Advanced Education Bill’, 28 Mar. 1990, 884-5, <http://parlinfo.parliament.qld.gov.au/isysquery/a5aa8a10-49b7-4aa6-811e-

e5fe39445260/7/doc/900328ha.pdf\#xml=http://parlinfo.parliament.qld.gov.au/isysquery/a5aa8a10-49b7-4aa6-811e-

e5fe39445260/7/hilite/>, accessed 14 Aug. 2010.

Queensland Performing Arts Centre, Treading the boards : a survey of theatre buildings in Brisbane, 1847-1998 (Brisbane:

Queensland Performing Arts Centre, 1999).

Roennfeldt, Peter, 'The genealogy and anatomy of the Australian tertiary music sector: How far have we come and where are

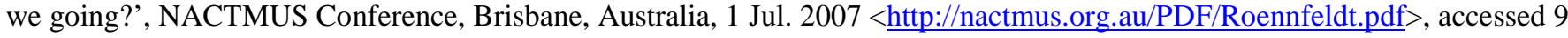
Aug. 2010.

Rogers, Frederic, ‘Queensland needs a Conservatorium of Music’, Brisbane Telegraph, 2 Feb. 1946, 2.

Rogers, Frederic, 'A Piece of News That Should Make Brisbane Blush: Big City Takes a Bad Beating,' Brisbane Telegraph, 3

Nov. 1951, 4.

Rogers, Frederic, ‘A Memorial Con? Music Loses a Friend’, Brisbane Telegraph, 19 Jan. 1952, 12.

Rogers, Frederic, 'Frederic Rogers records: The Birth of the Con', Brisbane Telegraph, 23 Feb. 1957, 15.

Rogers, Frederic, 'Fine work by choirs', Brisbane Telegraph, 16 May 1957, 18.

Rogers, Frederic, 'A new face, new era in State orchestra’, Sunday Mail, 29 May 1960, 32.

Rogers, Frederic, 'Choral articulation was unusually clear', Sunday Mail, 20 May 1984, 54.

Rowbotham, David, 'Opening a 'Cloud 9' event', The Courier-Mail, 22 Apr. 1985, 14.

Sampson, George, ‘The Need of a Conservatorium or School of Music for Brisbane’, Brisbane Music Week (1927): 26.

Tregear, Peter, The Conservatorium of Music, University of Melbourne: An Historical Essay to Mark its Centenary, 1895-1995

(Melbourne: Centre for Studies in Australian Music, 1997).

University of Melbourne, 'University provides strong support to VCAM, <htpp://blogs.unimelb.edu.au/musse/?p=1300>, accessed 14 Aug. 2010; and 'The Australian: VCA = \$ for Uni Melb’ < http://savevca.org/archives/750>, accessed 14 Aug. 2010.

Villaume, John, 'Music Festival ... in retrospect', The Courier-Mail, 11 Aug. 1981, 2.

Villaume, John, 'Students triumph', The Courier-Mail, 6 Apr. 1982, 2

Villaume, John, 'Opera on the move', The Courier-Mail, 5 Aug. 1983, 2.

Villaume, John, “Aida’ a spectacular triumph’, The Courier-Mail, 9 Aug 1985, 11.

Villaume, John, ‘Bernstein's 'Mass' packs Concert Hall to capacity’, The Courier-Mail, 12 Apr. $1986,41$.

Villaume, John, 'The Grand Vision of Berlioz', The Courier-Mail, 7 Jun. 1986, 40.

Wales, Roy, 'Opera role fills a local need', The Courier-Mail, 30 May 1984, 20.

Wilson, Rebecca, 'Ethnic Music Week', The Courier-Mail, 12 May 1983, 2.

Wiseman, Kenneth, From Park to Palace: A History of the Newcastle Conservatorium of Music, 1952-1986 (Newcastle: New South Wales Conservatorium, 1988).

Unsigned publications in chronological order:

'Conservatorium of Music: Mr Scarlett’s Views’, Daily Mail, 15 Apr. 1920, 4.

'Round the Studios', Australian Musical News, Dec. 1949, 36.

'Move on Conservatorium by State Govt.', Brisbane Telegraph, 29 Jan. 1952, 2. 
'If Women ran Queensland', The Courier-Mail, 5 Jan. 1953, 6.

'State Aid for Music', The Courier-Mail, 13 Feb. 1957, 2.

'Worth a fanfare', The Courier-Mail, 16 Feb. 1957, 1.

'Conservatorium seen as State cultural event', Brisbane Telegraph, 16 Feb. 1957, 3.

'130 Brushing up on Music', Courier-Mail, 17 Aug. 1957, 6.

'Boys too shy, so girls are tops (or so he says)', Truth, 24 Nov. 1957, 14.

'290 at music set a problem', The Courier-Mail, 11 Feb. 1958, 5.

'Has won three scholarships', Brisbane Telegraph, 19 Mar. 1958, 5.

'Music needs 'key men’', The Courier-Mail, 9 Apr. 1958, 12.

'Local singers for opera', The Courier-Mail, 5 May 1958, 5.

‘£40,000 operas on way’, The Courier-Mail, 11 Jun. 1958, 12.

'Future of state music', The Courier-Mail, 9 Jun. 1959, 2.

'Lovelock hits rules thought', Brisbane Telegraph, 12 Jun. 1959, 4.

'The accent's on music: Catering for all at 'Con', The Courier-Mail, 9 Feb. 1960, 5.

'Concrete music recital', The Courier-Mail, 4 May 1962, 2.

'Music brains lost to State,' The Courier-Mail, 21 Nov. 1963, 8.

'Something wrong with music policy', The Courier-Mail, 7 Oct. 1964, 13.

'Chorus for opera', The Courier-Mail, 4 Aug. 1966, 5.

'Opposed to arts division', The Courier-Mail, 17 Aug. 1973, 11.

'Music lovers rally to save conservatorium', The Courier-Mail, 6 Jul. 1981, 1.

'Cabinet rejects tertiary mergers', The Courier-Mail, 8 Jul. 1981, 10.

'Conservatorium merger 'killed’', The Courier-Mail, 11Jul. 1981, 2.

'State choir wants voices', The Courier-Mail, 25 Sep. 1983, 24.

'Griffith and Conservatorium to amalgamate', The Courier-Mail, 11 Dec. 1990, 13.

'Music moves to South Bank', The Courier-Mail, 18 Dec. 1992, 2.

'Facing the Music', Wikipedia article, <http://en.wikipedia.org/wiki/Facing_the_Music>, accessed 14 Aug. 2010.

Lloyd Vick: Represented Artist, Australian Music Centre, <http://www.australianmusiccentre.com.au/artist/vick-lloyd>, accessed 10 Aug. 2010.

William Lovelock (1899-1986): Represented Artist, Australian Music Centre,

<http://www.australianmusiccentre.com.au/artist/lovelock-william>, accessed 14 Aug. 2010. 